\title{
PENGARUH TEMPERATUR DAN UKURAN BUTIR TERHADAP KELARUTAN KALIUM PADA BATUAN LEUSITIK GUNUNG MURIA JAWA TENGAH
}

\author{
Effect of Temperature and Grain Size on Potassium Solubility in \\ Leusitic Rock from Muria Mountain, Central Java
}

\author{
BUDHY AGUNG ${ }^{1,2}$, ILDREM SYAFRI ${ }^{2}$ dan AGUS D. HARYANTO \\ 1 Puslitbang Teknologi Mineral dan Batubara \\ Jalan Jenderal Sudirman 623 Bandung 40211 \\ Telp. (022) 6030483, Fax. (022) 6003373 \\ e-mail: budhyas2017@gmail.com \\ 2 Universitas Padjadjaran \\ Jalan Dipatiukur No. 35 Bandung
}

\begin{abstract}
ABSTRAK
Mineral yang berpotensi di bidang pertanian sebagai sumber unsur hara (pupuk) yang dibutuhkan tanaman adalah dolomit, batuan fosfat, dan mineral silikat seperti leusit, muskovit dan ortoklas. Leusit mengandung kalium dan aluminium tektosilikat $\mathrm{K}\left(\mathrm{AlSi}_{2} \mathrm{O}_{6}\right)$. Mineral ini dijumpai di Kabupaten Jepara, Pati dan Kudus. Di Medani, Jepara potensinya sebanyak 190.400 .000 ton, kandungan $\mathrm{K}_{2} \mathrm{O}$ antara 1,92-8,77 \%. Mineral leusit untuk penelitian ini mempunyai kadar $\mathrm{K}_{2} \mathrm{O}$ antara 7,68-7,98 \%; $\mathrm{Al}_{2} \mathrm{O}_{3}$ 19,62-20,73\% dan $\mathrm{SiO}_{2}$ 48,62-49,93\%. Hasil analisis petrografi menunjukkan adanya fenokris yang terdiri dari leusit, sanidin dan mineral opak. Unsur kalium di dalam leusit sulit larut, sehingga perlu diupayakan peningkatan kelarutannya dengan cara memanaskan batuan mengandung leusit tersebut pada suhu $600-1000{ }^{\circ} \mathrm{C}$ dan penghalusan ukuran butiran dari -70 sampai -200 mesh. Sebagai pembanding digunakan percontoh tanpa pemanasan. Dari hasil uji coba, kelarutan tanpa pemanasan relatif rendah antara 0,22-0,49\%; semakin halus butiran kelarutan leusit cenderung semakin meningkat, tetapi pada suhu $600{ }^{\circ} \mathrm{C}$ terjadi peningkatan cukup signifikan antara $1,55-2,30 \%$, pada suhu $700{ }^{\circ} \mathrm{C}$ kelarutan relatif tetap yaitu antara $1,44-2,40 \%$, sedangkan pada suhu $850{ }^{\circ} \mathrm{C}$ mulai terjadi penurunan kelarutan menjadi 1,20 $1,95 \%$ dan pada suhu lebih tinggi $1000{ }^{\circ} \mathrm{C}$, kelarutan menurun menjadi 0,31-0,45 \%. Percobaan peningkatan kelarutan kalium cukup signifikan sampai 10 kali, diharapkan kegunaan untuk pupuk lebih baik.
\end{abstract}

Kata kunci: mineral leusit, potensi, kelarutan kalium, pupuk

\begin{abstract}
The potential mineral as a source of nutrients (fertilizers) needed by plants, are dolomite, phosphate rocks, and silicate minerals such as leucite, muskovite and orthoclase. Leucite contains potassium and aluminum tectosilicate or $\mathrm{K}\left(\mathrm{AlSi}_{2} \mathrm{O}_{6}\right)$. It is found in Jepara, Pati and Kudus provinces. The potential leucite of Medani at Jepara is $190,400,000$ tons, and the $\mathrm{K}_{2} \mathrm{O}$ content is between $1.92-8,77 \%$. Leucite mineral for the study had $\mathrm{K}_{2} \mathrm{O}$ content between 7.68-7.98 \%, $\mathrm{Al}_{2} \mathrm{O}_{3}$ 19.62-20.73\% and $\mathrm{SiO}_{2} 48.62-49.93 \%$. Results of petrographic analysis showed the phenocryst consisted of leucite, sanidine and opaque minerals. The potassium element within the leucite is difficult to dissolve, therefore it is necessary to increase its solubility by heating the rocks at temperatures of $600-1000{ }^{\circ} \mathrm{C}$ and ground the grain into the fine sizes from -70 to -200 mesh. As a comparison, it used the samples without heating. The results showed that the solubility of materials without heating were relatively low, between 0.22-0.49\%. It showed that the finer the grain the more increase the
\end{abstract}


solubility. There is a significant increase between $1.55-2.30 \%$, at a temperature of $600{ }^{\circ} \mathrm{C}$ while at a temperature of $700{ }^{\circ} \mathrm{C}$ the relative solubility is still between $1.44-2.40 \%$. Increasing the-temperature to $850{ }^{\circ} \mathrm{C}$ starts decreasing the solubility to $1.20-1.95 \%$, at $1000{ }^{\circ} \mathrm{C}$, the solubility decreases to $0.31-0.45 \%$. Experiments to increase the solubility potassium are quite significant until 10 times. It is expected that the use of leucite mineral as fertilizers will be better.

Keywords: Leucite minerals, potency, potassium solubility, fertilizer

\section{PENDAHULUAN}

Mineral yang berpotensi di bidang Pertanian sebagai sumber unsur hara (pupuk) yang dibutuhkan tanaman, adalah dolomit, batuan fosfat, dan mineral silikat seperti muskovit, ortoklas, biotit, ilit, mika, vermikulit, leusit dan lain lain. Fosfat, sumber endapannya dapat berasal dari batuan beku, sedimen atau massa tanah. Lokasi endapan fosfat di antaranya di Jawa dan Madura (Wahyudi dkk., 2008).

Kebutuhan pupuk berbahan dasar fosfat di Indonesia sangat besar dan diperkirakan akan semakin meningkat dari tahun ke tahun. Persyaratan yang diajukan oleh produsen pupuk adalah $36 \% \mathrm{P}_{2} \mathrm{O}_{5}$. Hal ini sangat kontras dengan kondisi endapan fosfat di Indonesia yang umumnya mempunyai kadar relatif rendah $( \pm 20-30 \%)$ dan keterdapatannya tersebar dengan kuantitas yang kecil (Sudradjat $d k k ., 1997)$.

Dolomit termasuk rumpun mineral karbonat yang secara teoritis mengandung 45,6\% $\mathrm{MgCO}_{3}$, atau 21,9 \% MgO. Kandungan magnesium dalam dolomit yang cukup tinggi, membuatnya potensial untuk dimanfaatkan sebagai bahan baku pembuatan pupuk mineral berbasis dolomit. Keterdapatannya di antaranya di Jawa Tengah, Jawa Timur, Madura dan Papua (Sudradjat dkk., 1997; Supriyanto $d k k$. , 2015).

Leusit terdapat di batuan basal yang terdiri dari kalium dan aluminium tektosilikat $\mathrm{K}\left(\mathrm{AlSi}_{2} \mathrm{O}_{6}\right)$. Mineral ini komposisinya mirip dengan alkali felspar tetapi kandungan silikanya sedikit, disebut felspatoid. Leusit ditemukan pada batuan yang sedikit mengandung silika. Pada saat pembentukan mineral, jika saat meleleh terdapat kuarsa, silika akan bereaksi dengan felspatoid membentuk felspar. Leusit merupakan sumber kalium dan aluminium, Indonesia mempunyai potensi bahan-bahan mineral yang dapat diinventarisasi sebagai bahan baku alternatif pupuk K. Bahan-bahan tersebut adalah felspar, mika, biotit, muskovit, flogopit dan leusit. Deposit batuan basalt pembawa mineral leusit tersebar di Jawa, Sumatera, dan Sulawesi dalam spot-spot tertentu (Supriyanto dkk., 2015).

Di Jawa, batuan basalt ini dijumpai di Kabupaten Jepara, Pati dan Kudus, tersebar di Kecamatan Cluwak, Gunungwungkal dan Tlogowungu. Batuan pembawa kalium tersebar di lima blok (Gambar 1). Potensi mineral leusit yang terdapat di Gunung Muria meliputi Kabupaten Jepara dan Pati, tersebar di 5 lokasi dengan potensi mencapai ratusan juta ton dengan kualitas kandungan $\mathrm{K}_{2} \mathrm{O}$ cukup tinggi mencapai $8,77 \%$. $\mathrm{SiO}_{2}$ berkisar 40,2-53,57\% seperti dapat dilihat pada Tabel 1. Mineral pembentuk itu diketemukan juga batuan pembawa kalium (berupa tuf) yang tersebar di dua blok, yakni Blok Wedusan (T1) berupa sumberdaya tereka 16.500 .000 ton, dan kandungan $\mathrm{K}_{2} \mathrm{O}$ berkisar 4,41-4,54 \%, Blok Mojo (T-2) dengan sumberdaya tereka 115.920.000 ton, kandungan $\mathrm{K}_{2} \mathrm{O}$ berkisar 0,84-8,79 \% (Muksin dan Karangan, 2016).

Cara untuk meningkatkan kelarutan kalium pada mineral kalium silikat dilakukan dengan memanaskan batuan yang telah dihaluskan pada suhu sekitar $600{ }^{\circ} \mathrm{C}$ dan menambahkan sumber alkali misalnya $\mathrm{NaOH}$ (Han, Liu dan Yin, 2008). Uji coba pada batuan leusitik juga telah dilakukan dengan cara menambahkan $\mathrm{NaOH}$ pada variasi suhu $500-900{ }^{\circ} \mathrm{C}$ (Wahyudi $d k k ., 2012)$. Penelitian terhadap batuan silikat lainnya yaitu talk. Kelarutan Mg pada suhu kamar hanya 9,38\%, tetapi setelah percontoh tersebut dipanaskan $700{ }^{\circ} \mathrm{C}$, kelarutannya meningkat menjadi 64,51 \% (Erpian, Agung dan Budiman, 2011). Uji skala laboratorium menunjukkan bahwa kelarutan kalium dari mineral silikat felspar juga lambat. Berbagai uji telah dilakukan untuk meningkatkan kelarutan kalium antara lain dengan cara penggerusan bahan tersebut, juga melalui kalsinasi atau pelindian asam (Wang $d k k ., 2014)$. 
Pengaruh Temperatur dan Ukuran Butir Terhadap Kelarutan Kalium ... Budhy Agung dkk.

Tabel 1. Lima lokasi Gunung Muria yang mempunyai potensi batuan basalt pembawa mineral leusit

\begin{tabular}{clccc}
\hline \multirow{2}{*}{ No } & \multirow{2}{*}{ Lokasi } & $\begin{array}{c}\text { Potensi Tereka } \\
\text { Juta Ton }\end{array}$ & $\begin{array}{c}\text { Kadar } \\
\mathrm{K}_{2} \mathrm{O}(\%)\end{array}$ & $\begin{array}{c}\text { Kadar } \\
\mathrm{SiO}_{2}(\%)\end{array}$ \\
\hline 1 & Medani & 190,400 & $1,92-8,77$ & $40,23-53,7$ \\
2 & Sentul & 176,880 & $6,61-7,87$ & $46,86-49,03$ \\
3 & Jrahi & 25,470 & $2,67-3,25$ & $42,04-50,22$ \\
4 & Poh Gading & 104,370 & $3,16-4,51$ & $44,60-44,81$ \\
5 & Plukaran & 36,790 & $4,40-5,00$ & $45,66-46,64$ \\
\hline
\end{tabular}

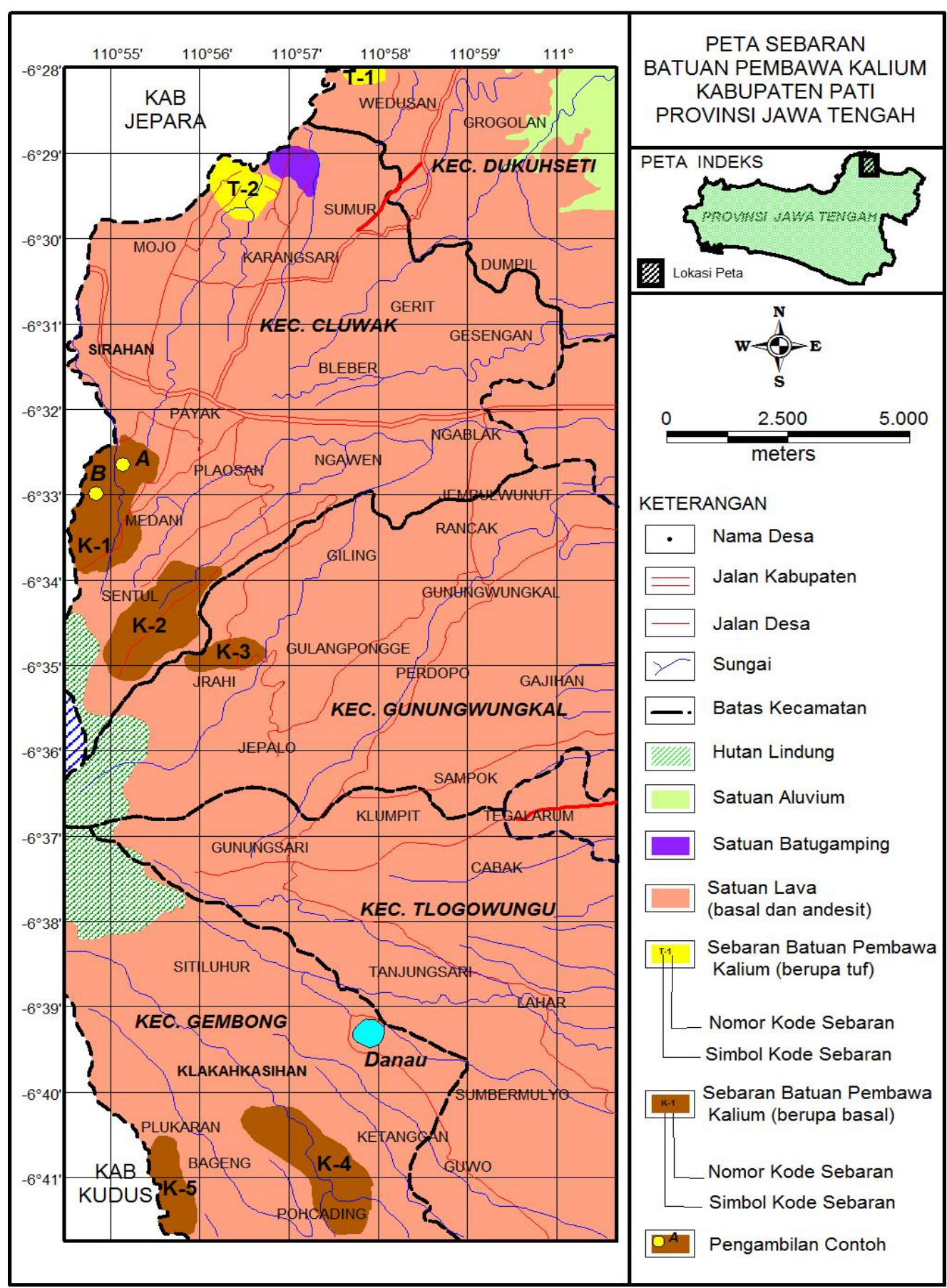

Gambar 1. Peta sebaran batuan pembawa kalium, Kabupaten Pati Provinsi Jawa Tengah (Muksin dan Karangan, 2016) 


\section{METODE}

Bahan baku batuan leusitik yang digunakan untuk penelitian ini berasal dari daerah Medani, Kabupaten Jepara - Pati Jawa Tengah. Secara garis besar rangkaian kegiatan penelitian yang dilakukan dibagi menjadi tiga tahap, yaitu:

1. Studi pustaka dan menyiapkan batuan leusitik, yang dimulai dengan pemercontohan batuan yang mewakili dari daerah Medani, preparasi percontoh untuk penelitian yang diawali dengan peremukan, penggerusan dan dilanjutkan dengan analisis ayak ukuran yang dikehendaki (Soenara $d k k ., 2011$ ).

2. Karakterisasi batuan leusitik meliputi analisis geokimia, X-RF, X-RD dan petrografi, untuk memastikan kesesuaian batuan leusitik yang diinginkan dan kandungan $\mathrm{K}_{2} \mathrm{O}$ nya. Analisis tersebut di atas dilakukan di Laboratorium Pengujian Pusat Penelitian Pengembangan Teknologi Mineral dan Batubara (tekMIRA) Bandung.

3. Uji peningkatan kelarutan kalium dilakukan dengan rancangan sebagai berikut:

- dari beberapa percontoh yang diperoleh di lapangan dipilih satu percontoh untuk uji peningkatan kelarutan kalium dengan metode split plot acak lengkap dengan 4 variasi ukuran butiran, 70, 100, 140 dan 200 mesh.

- ukuran butir sebagai petak utama (PU) dan 5 variasi temperatur, 30, 600, 700, 850 dan $1000{ }^{\circ} \mathrm{C}$ sebagai anak petak (AP) pada masing masing uji dilakukan 3 kali pengulangan. Semua hasil uji tersebut di atas kemudian dianalisis dengan uji kelarutan kalium menggunakan asam sitrat dan asam klorida.

\section{Peralatan}

Peralatan yang digunakan untuk penelitian meliputi:

- 1 unit peremuk rahang (jaw crusher) (kapasitas 200-250 kg/jam, ukuran umpan 4", dan produk 1")

- 1 unit peremuk rol (roll crusher) (kapasitas 20-40 kg/jam)

- 1 unit pelumat cincin (ring mill) (kapasitas $1 \mathrm{~kg} / \mathrm{jam})$

- 4 buah ayakan masing-masing 1 buah (ukuran 70, 100, 140 dan 200 mesh)
- 1 unit tanur (furnace) dengan dimensi $30 \mathrm{x}$ $20 \times 15 \mathrm{~cm}^{3}$ suhu maksimum $1500{ }^{\circ} \mathrm{C}$.

\section{Prosedur Penelitian}

Rangkaian tahapan penelitian batuan leusitik daerah Medani ditampilkan pada Gambar 2.

\section{HASIL DAN PEMBAHASAN}

Potensi sumberdaya mineral non logam leusit yang ada di Indonesia saat ini belum banyak dieksplorasi. Mineral ini kandungan unsur kaliumnya cukup tinggi mencapai $12 \%$, tetapi kondisi ini kurang diminati karena kelarutannya rendah. Kelarutan batuan beku yang banyak mengandung kalium mempunyai kelarutan umumnya di bawah 10 \% (Wahyudi dkk., 2012). Untuk mengatasi hal tersebut perlu penelitian menggunakan parameter temperatur dan ukuran butir mineral dimaksudkan untuk meningkatkan kelarutan kalium tersebut.

Batuan pembawa kalium yang pada umumnya berupa batuan bersifat basalt, terdapat di Gunung Muria dan tersebar di Kabupaten Jepara dan Pati, yakni di Medani, Sentul, Jrahi, Poh Gading dan Plukaran. Potensi dan kandungan kaliumnya ditampilkan pada Tabel 1 dan sebarannya dapat dilihat pada Gambar 1 .

Untuk penelitian ini percontoh diambil dari daerah Medani Jepara, walaupun ke lima daerah mempunyai kadar kalium yang beragam tetapi daerah Medani mempunyai kadar $\mathrm{K}_{2} \mathrm{O}$ mencapai $8,77 \%$ dengan potensi mencapai 190.400.000 ton.

Di lain pihak impor pupuk yang berbasis kalium mencapai 435.000 ton/tahun (Wardama dan Titisari, 2004). Perkebunan teh di Jawa Barat saja membutuhkan 1.599,9 ton (Saleh $d k k$., 2014) sehingga potensi untuk pemanfaatan pupuk dalam negeri mampu bersaing dengan pupuk impor. Pupuk K konvensional saat ini diproduksi secara umum dari tambang garam terutama silvit $(\mathrm{KCl})$ dan karnalit $\left(\mathrm{MgCl}_{2} \mathrm{KCl} .6 \mathrm{H}_{2} \mathrm{O}\right)$ atau air laut. Ketiga jenis material tersebut hanya memerlukan sedikit pemrosesan secara kimiawi untuk menghasilkan produk berbasis pupuk (Ciceri, Manning dan Allanore, 2015). 
Sekitar 39 juta ton $\mathrm{K}_{2} \mathrm{O}$ setara tambang dipasok dari 12 negara. Produksi dunia didominasi oleh 10 perusahaan besar sebagian besar berasal dari Amerika, Belarus, dan Rusia (Jasinski, 2016).

Untuk uji pemanfaatan pada tanaman teh, jika dibandingkan dengan pupuk standar, penggunaan mineral leusit mampu menaikkan produktivitas 10,58 \% (Suganal $d k k$., 2016). Demikian juga pada uji dengan tanaman kedelai, jika dibandingkan dengan pupuk standar penggunaan mineral leusit mampu menaikkan produktivitas sebesar 20,9\% (Sayekti, 2015).
Hasil percobaan yang akan dibahas meliputi karakteristik bahan baku dengan metode analisis geokimia dan petrografi, juga kelarutan kalium di dalam batuan setelah uji coba.

Hasil analisis kimia percontoh menunjukkan bahwa batuan leusitik mempunyai kandungan $\mathrm{K}_{2} \mathrm{O}$ antara 7,68-7,98 \%, $\mathrm{Al}_{2} \mathrm{O}_{3}$ 19,62-20,73 $\%, \mathrm{Fe}_{2} \mathrm{O}_{3}$ 6,22-6,36 \% dan $\mathrm{SiO}_{2}$ 48,62-49,93 $\%$ (Tabel 2). Batuan ini mempunyai kadar $\mathrm{K}_{2} \mathrm{O}$ relatif tinggi, berwarna putih yang tertanam dalam masa dasar mikrolit (Gambar 3). Kandungan kalium tinggi dalam mineral tersebut kurang disukai karena kelarutannya relatif rendah, sehingga untuk kegunaan pada tanaman yang memerlukan unsur hara kalium kelarutannya perlu ditingkatkan.

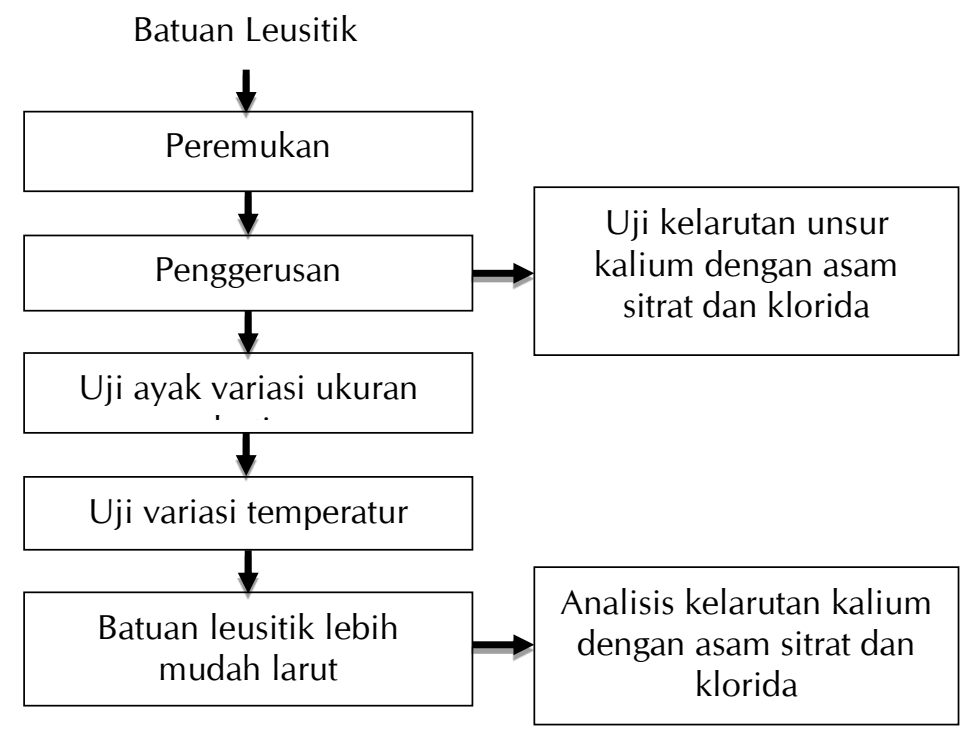

Gambar 2. Bagan alir penelitian peningkatkan kelarutan unsur kalium pada batuan leusitik dengan variasi ukuran dan temperatur

Tabel 2. Analisis AAS percontoh leusit Medani beragam ukuran butir

\begin{tabular}{ccccc}
\hline \multirow{2}{*}{ Unsur (\%) } & \multicolumn{4}{c}{ Kode Percontoh } \\
\cline { 2 - 5 } & Leu-70 & Leu-100 & Leu-140 & Leu-200 \\
\hline $\mathrm{SiO}_{2}$ & 49,93 & 49,12 & 48,62 & 48,90 \\
$\mathrm{Al}_{2} \mathrm{O}_{3}$ & 19,62 & 19,76 & 20,55 & 20,73 \\
$\mathrm{Fe}_{2} \mathrm{O}_{3}$ & 6,33 & 6,36 & 6,24 & 6,22 \\
$\mathrm{~K}_{2} \mathrm{O}$ & 7,68 & 7,91 & 7,94 & 7,98 \\
\hline
\end{tabular}




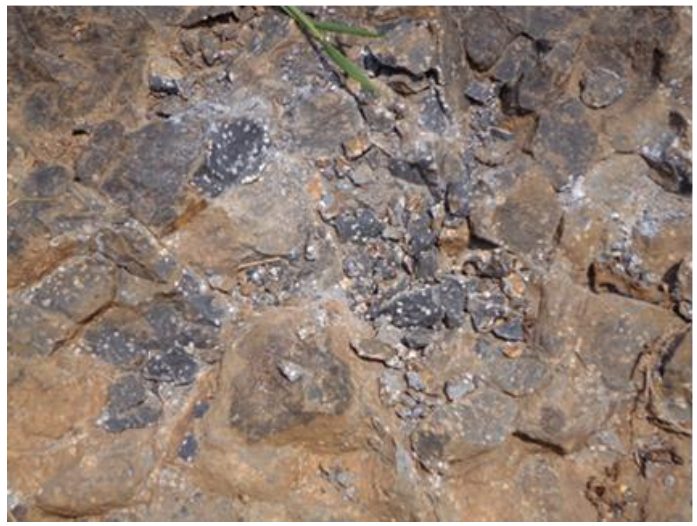

Gambar 3. Kristal leusit (bintik putih) tertanam dalam masa dasar mikrolit plagioklas (abu-abu kehitaman)

\section{Analisis Petrografi}

Analisis petrografi dilakukan pada sayatan tipis batuan dasar percontoh leusitik yang relatif segar menggunakan mikroskop polarisasi. Hasil analisis Petrografi dapat dilihat pada Gambar 4. Sayatan batuan menunjukkan tekstur holokristalin, porfiroafanitik dengan struktur masif. Komposisi mineral terdiri dari fenokris leusit, sanidin, dan mineral opaqe yang tertanam pada massa dasar berupa microlite. Mineral sekunder yang hadir berupa mineral lempung dan kalsit sebagai ubahan dari mineral primer plagioklas.

Fenokris terdiri dari :

- leusit (35\%): tidak berwarna pada nikol sejajar dan berwarna abu-abu gelap kehitaman pada nikol bersilang, relief sedang, berukuran kristal 0,4-19 mm, bentuk euhedral, oktagonal;

- $\operatorname{sanidin}(4,8 \%)$ : tidak berwarna pada nikol sejajar dan berwarna abu-abu pada nikol bersilang, relief sedang, berukuran kristal
0,5-4,7 mm, bentuk subhedral, prismatik panjang, kembaran carlsbad;

- mineral opaqe (2,8 \%): berwarna hitam pada nikol sejajar maupun pada nikol bersilang, relief tinggi, bentuk euhedral, berukuran 0,07-0,47 $\mathrm{mm}$.

Massa dasar terdiri dari microlite $(32,6 \%)$. Pada nikol sejajar tidak berwarna sedangkan pada nikol bersilang berwarna putih-abu-abu, hadir berupa material halus, bentuk kristalinmenjarum, terdiri atas mikro-granular felspar.

Mineral sekunder terdiri dari:

- mineral lempung (13,6 \%). Tidak berwarna pada nikol sejajar dan berwarna putih kekuningan pada nikol bersilang, berukuran halus $(<0,005 \mathrm{~mm})$, dominan hadir menggantikan massa dasar microlite;

- kalsit (11,2 \%). Tidak berwarna pada nikol sejajar dan berwarna merah muda-hijau pada nikol bersilang, berukuran kristal 0,10,3 mm, memiliki kembaran polisintetik, berbentuk butiran dan hadir menggantikan sanidin serta mengisi rekahan membentuk urat-urat tipis dengan ketebalan 0,02-0,06 $\mathrm{mm}$;

- leusit mengisi rekahan dan rongga berbentuk bulat tidak beraturan dan berukuran 0,4 $\mathrm{mm}$.

Untuk uji kelarutan kalium pada leusit ada delapan percontoh yang masing-masing diambil sebanyak lima kilogram secara acak pada beberapa tempat/titik di daerah tersebut. Untuk mengetahui besarnya kandungan kalium dalam batuan, dilakukan analisis AAS. Hasil uji menunjukkan kadar kalium berkisar antara $6,91-9,22 \%$ (Tabel 3). Dalam penelitian ini telah dipilih percontoh dengan kadar kalium $7,88 \%$. Percontoh ini dipilih karena mendekati angka rata-rata percontoh yang ada.

Tabel 3. Analisis AAS percontoh leusit dari daerah Medani

\begin{tabular}{lllllllll}
\hline \multirow{2}{*}{ Unsur (\%) } & \multicolumn{7}{c}{ Kode Percontoh } \\
\cline { 2 - 9 } & LST-1 & LST-2 & LST-3 & LST-4 & LST-5 & LST-6 & LST-7 & LST-8 \\
\hline $\mathrm{SiO}_{2}$ & 47,35 & 47,55 & 47,93 & 48,03 & 47,85 & 48,28 & 48,73 & 48,44 \\
$\mathrm{Al}_{2} \mathrm{O}_{3}$ & 19,48 & 19,37 & 20,24 & 20,08 & 23,27 & 24,71 & 23,29 & 23,99 \\
$\mathrm{~K}_{2} \mathrm{O}$ & 6,91 & 7,11 & 7,88 & 7,21 & 9,22 & 8,36 & 9,04 & 8,59 \\
$\mathrm{CaO}$ & 8,33 & 8,23 & 7,00 & 7,32 & 4,55 & 4,32 & 4,38 & 4,30 \\
$\mathrm{MgO}$ & 1,81 & 1,81 & 1,60 & 1,66 & 1,23 & 1,08 & 1,12 & 1,04 \\
$\mathrm{P}_{2} \mathrm{O}$ & 0,24 & 0,32 & 0,17 & 0,20 & 0,28 & 0,25 & 0,21 & 0,23 \\
\hline
\end{tabular}



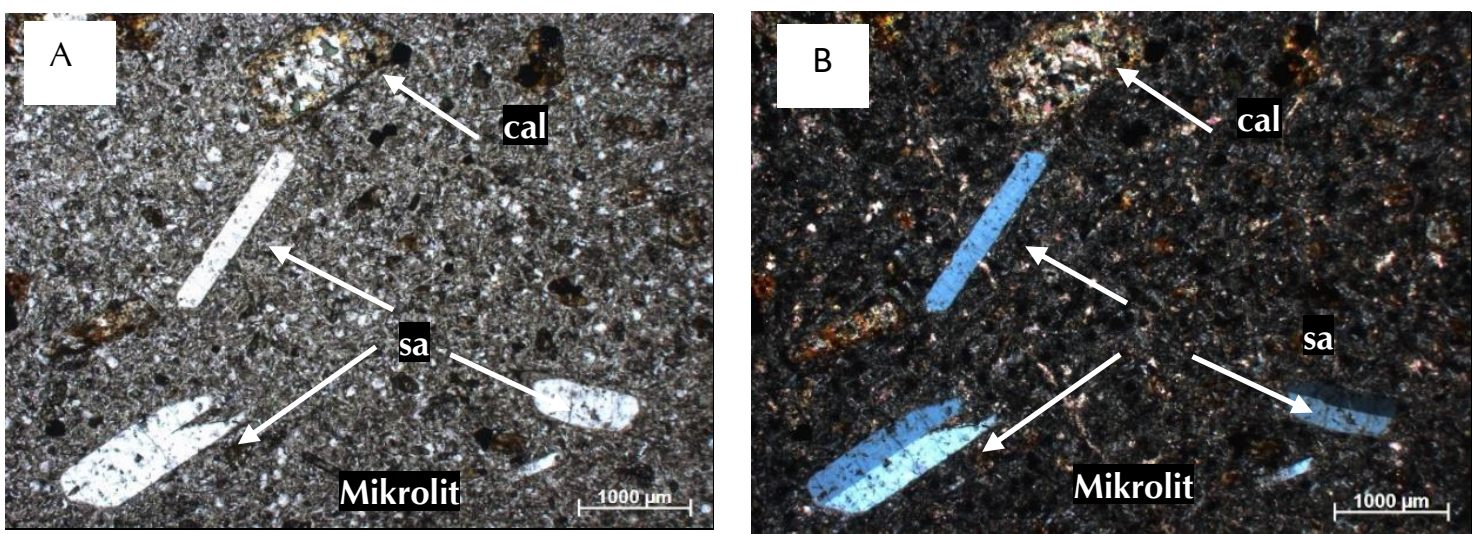

Foto 1. Fotomikrograf sayatan tipis [A] nikol sejajar, [B] nikol bersilang. Ket.: $\mathrm{cal}=$ kalsit, $\mathrm{sa}=$ sanidin.
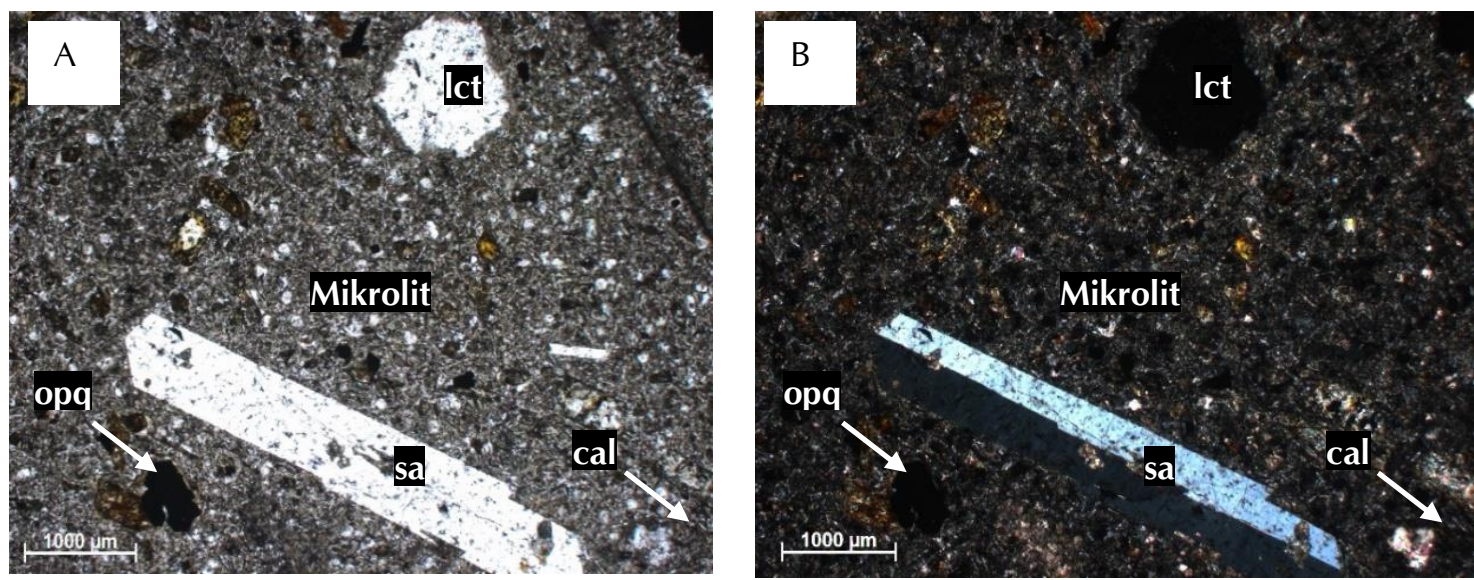

Foto 2. Fotomikrograf sayatan tipis $[\mathrm{A}]$ nikol sejajar, $[\mathrm{B}]$ nikol bersilang. Ket. : $c a l=$ kalsit, $l c t=$ leusit, opq $=$ mineral opaq.
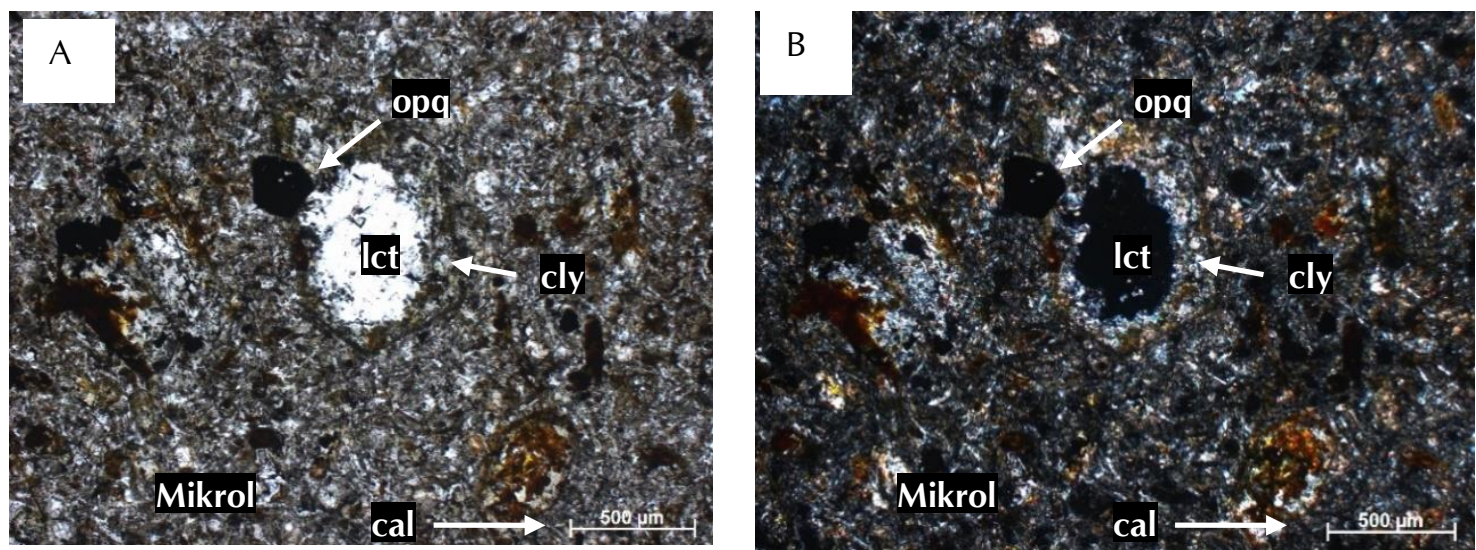

Foto 3. Fotomikrograf sayatan tipis $[\mathrm{A}]$ nikol sejajar, $[\mathrm{B}]$ nikol bersilang.

Ket.: $\mathrm{cal}=$ kalsit, $\mathrm{cly}=$ mineral lempung, $\mathrm{Ict}=$ leusit, $\mathrm{opq}=$ mineral opaq.

Gambar 4. Analisis petrografi batuan leusitik dari kawasan Medani Kabupaten Jepara Jawa Tengah 
Tahapan pengecilan ukuran mineral leusit adalah sebagai berikut:

1. Peremukan tahap pertama dengan ukuran bijih umpan sekitar 5-7 cm menjadi ukuran butir sekitar 1-2 cm;

2. Peremukan tahap kedua dengan ukuran umpan sekitar 1-2 cm menjadi ukuran sekitar 1-2 mm;

3. Penggerusan dengan menggunakan pelumat bola (ball mill) dengan ukuran umpan 1-2 mm menjadi -70 mesh sampai dengan -200 mesh.

Tahap pemanasan dilakukan dengan menggunakan furnace. Percontoh yang telah disiapkan berukuran $-70+100,-100+140$, -
$140+200$ dan -200 mesh. Setiap ukuran tersebut di atas dipanaskan pada suhu 600, 700, 850 dan $1000{ }^{\circ} \mathrm{C}$, serta dilakukan pengulangan untuk masing-masing percontoh sebanyak tiga kali.

\section{Uji Kelarutan dengan Asam Sitrat $2 \%$}

Pengujian ini dilakukan untuk mengetahui seberapa besar unsur kalium mampu larut dalam asam sitrat $2 \%$, menggambarkan kecepatan larut kalium dalam batuan tersebut pada berbagai ukuran butir dan variasi pemanasan percontoh. Hasil uji dengan variasi temperatur dan ukuran butir ditampilkan pada Tabel 4, Gambar 5 dan 6.

Tabel 4. Hasil uji kelarutan dengan $2 \%$ asam sitrat pada variasi ukuran butir dan temperatur

\begin{tabular}{|c|c|c|c|c|c|c|}
\hline \multirow{2}{*}{$\begin{array}{l}\text { Ukuran } \\
\text { Umpan }\end{array}$} & \multirow{2}{*}{$\begin{array}{c}\text { Ulangan } \\
(\%)\end{array}$} & \multicolumn{5}{|c|}{ Temperatur $\left({ }^{\circ} \mathrm{C}\right)$} \\
\hline & & 30 & 600 & 700 & 850 & 1000 \\
\hline \multirow{3}{*}{$-70+100$} & 1 & 0,22 & 1,85 & 1,91 & 1,20 & 0,31 \\
\hline & 2 & 0,25 & 1,90 & 2,1 & 1,30 & 0,45 \\
\hline & 3 & 0,27 & 1,87 & 2,0 & 1,25 & 0,35 \\
\hline \multirow{3}{*}{$-100+140$} & 1 & 0,46 & 1,55 & 1,44 & 1,25 & 0,21 \\
\hline & 2 & 0,38 & 1,80 & 1,75 & 1,40 & 0,40 \\
\hline & 3 & 0,40 & 1,70 & 1,60 & 1,23 & 0,42 \\
\hline \multirow{3}{*}{$-140+200$} & 1 & 0,49 & 1,86 & 1,93 & 1,82 & 0,38 \\
\hline & 2 & 0,43 & 2,19 & 2,20 & 1,90 & 0,43 \\
\hline & 3 & 0,40 & 2,10 & 2,0 & 1,80 & 0,45 \\
\hline \multirow{3}{*}{-200} & 1 & 0,36 & 2,57 & 2,34 & 1,86 & 0,22 \\
\hline & 2 & 0,45 & 2,25 & 2,40 & 1,95 & 0.35 \\
\hline & 3 & 0,40 & 2,30 & 2,35 & 1,81 & 0,45 \\
\hline
\end{tabular}

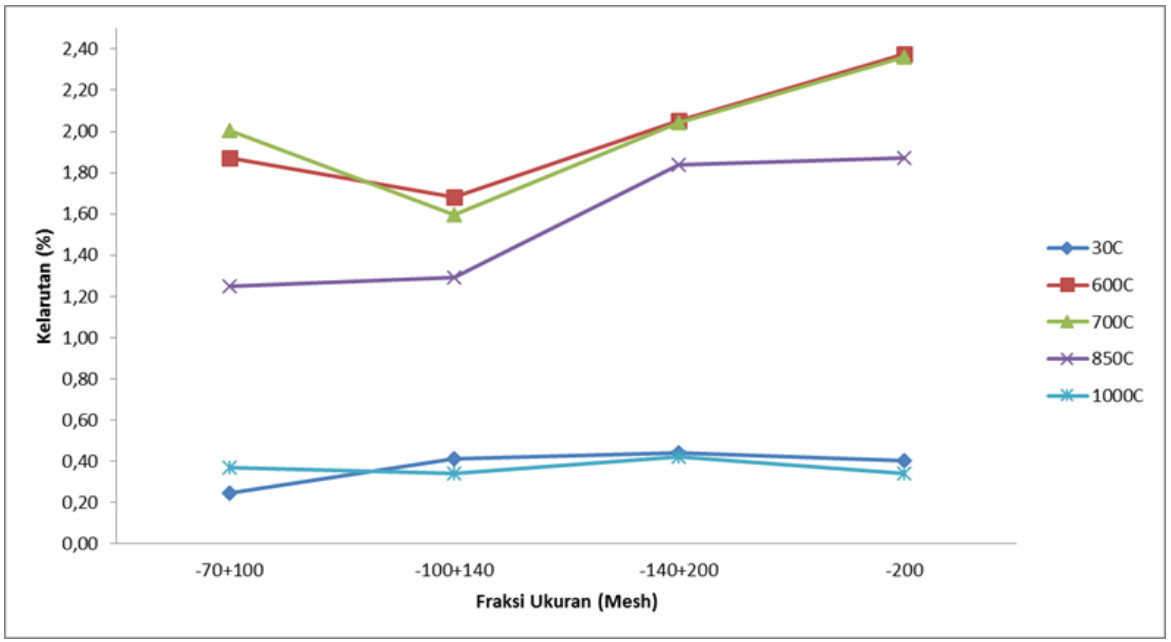

Gambar 5. Grafik kelarutan kalium dengan $2 \%$ asam sitrat pada variasi ukuran butir 


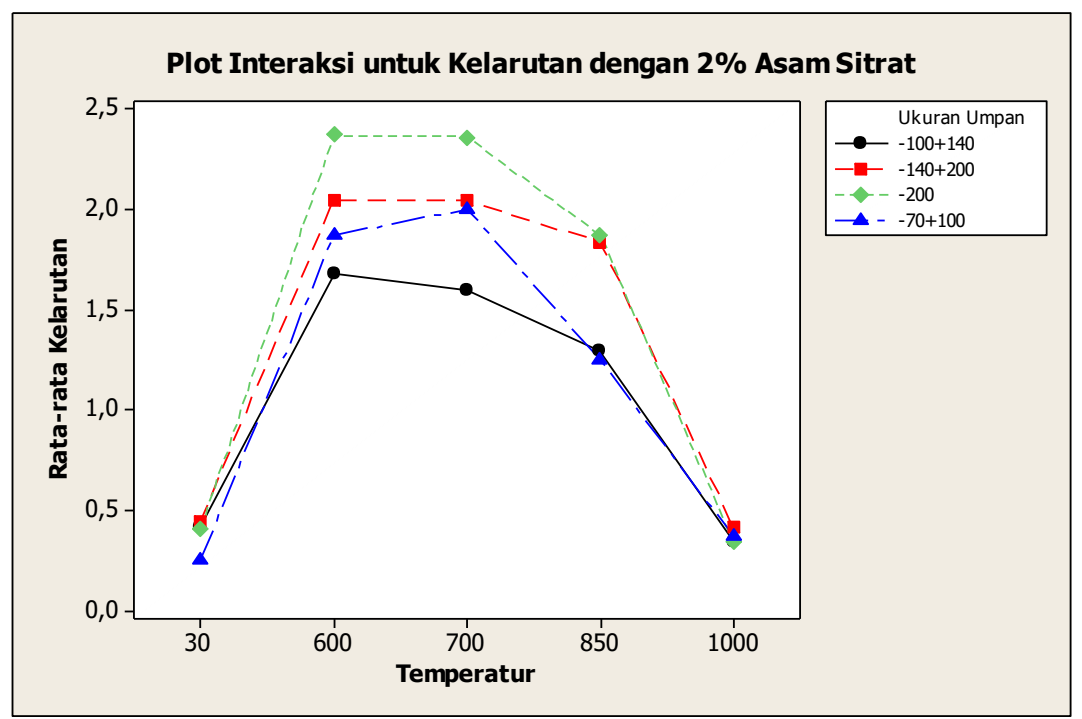

Gambar 6. Grafik kelarutan kalium dengan $2 \%$ asam sitrat untuk berbagai ukuran umpan dan berbagai-variasi temperatur

Dengan pengecilan ukuran butir terjadi kenaikan kelarutan. Pada ukuran relatif kasar -70 mesh, kelarutan K mencapai 0,24 \% dan ukuran butir -200 mesh kelarutannya meningkat $0,4 \%$. Hal ini disebabkan semakin kecil ukuran butir terjadi penambahan luas permukaan butiran. Demikian juga halnya dengan pemanasan, peningkatan kelarutan yang signifikan terjadi pada suhu $600{ }^{\circ} \mathrm{C}$, kelarutan $\mathrm{K}$ meningkat sampai $1,87 \%$. Secara kimiawi proses reaksi pelarutan kalium dengan asam sitrat adalah sebagai berikut:

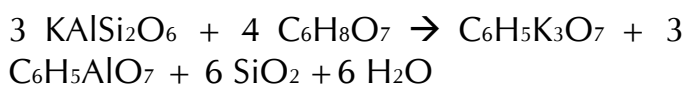

\section{Uji Kelarutan dengan Asam Klorida 25\%}

Sama halnya dengan asam sitrat, pengujian ini untuk mengetahui seberapa besar unsur kalium mampu larut pada batuan leusitik, pada berbagai ukuran umpan dan berbagai variasi temperatur.

Untuk uji kelarutan kalium pada batuan leusitik, hasil uji dengan variasi temperatur dan ukuran butir ditampilkan pada Tabel 5, Gambar 7 dan 8. Secara kimiawi proses pelarutan kalium dengan asam klorida adalah sebagai berikut (Vogel dan Svehla, 1979):

$3 \mathrm{KAISi}_{2} \mathrm{O}_{6}+12 \mathrm{HCl} \rightarrow 3 \mathrm{KCl}+3 \mathrm{AlCl}_{3}+$ $6 \mathrm{SiO}_{2}+6 \mathrm{H}_{2} \mathrm{O}$

Tabel 5. Hasil uji kelarutan (\%) dengan $25 \%$ asam klorida variasi ukuran butir dan temperatur

\begin{tabular}{ccccccc}
\hline \multirow{2}{*}{$\begin{array}{c}\text { Ukuran } \\
\text { Umpan }\end{array}$} & $\begin{array}{c}\text { Ulangan } \\
(\%)\end{array}$ & 30 & 600 & 700 & 850 & 1000 \\
\cline { 2 - 6 }$-70+100$ & 1 & 4,40 & 6,80 & 6,90 & 5,20 & 4,30 \\
& 2 & 3,40 & 7,20 & 8,10 & 6,10 & 4,00 \\
& 3 & 3,80 & 7,10 & 7,70 & 5,50 & 3,90 \\
\hline \multirow{3}{*}{$-100+140$} & 1 & 4,56 & 7,40 & 8,05 & 6,97 & 5,38 \\
& 2 & 4,10 & 7,10 & 8,20 & 6,60 & 4,70 \\
& 3 & 3,90 & 7,50 & 8,50 & 6,10 & 5,00 \\
\hline \multirow{3}{*}{$-140+200$} & 1 & 5,07 & 5,67 & 6,40 & 5,12 & 4,40 \\
& 2 & 4,80 & 6,50 & 7,80 & 6,30 & 3,90 \\
& 3 & 4,90 & 6,20 & 7,10 & 5,40 & 4,10 \\
\hline \multirow{3}{*}{-200} & 1 & 5,30 & 6,46 & 6,93 & 6,28 & 5,04 \\
& 2 & 5,0 & 6,90 & 7,60 & 6,50 & 4,70 \\
& 3 & 5,20 & 7,10 & 7,80 & 7,0 & 5,10 \\
\hline
\end{tabular}




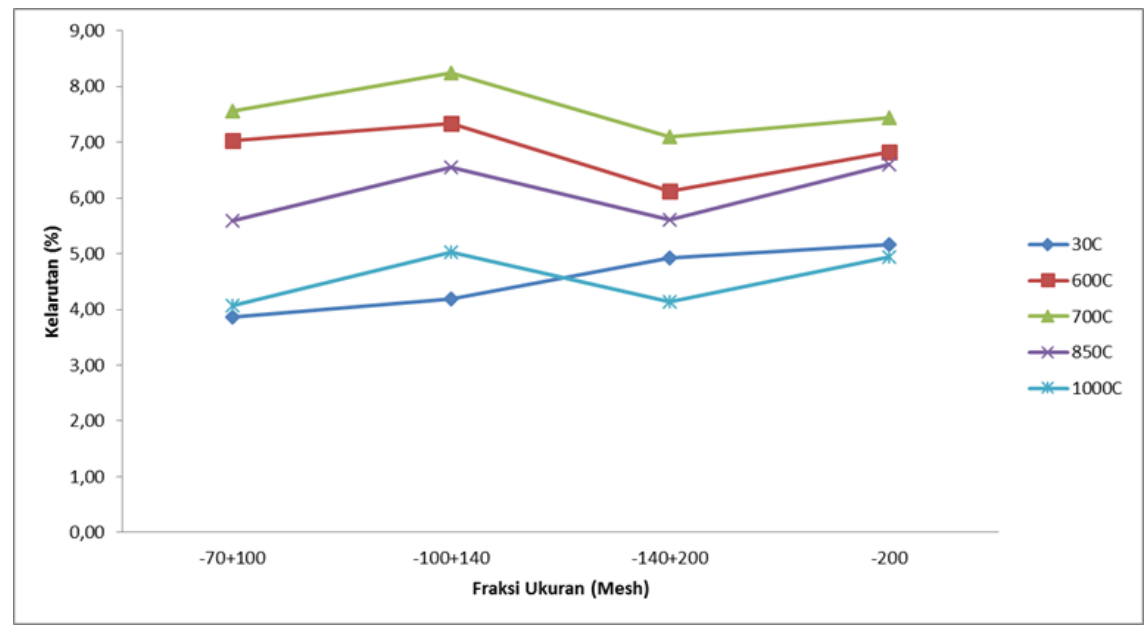

Gambar 7. Grafik kelarutan kalium dalam $25 \%$ asam klorida dengan variasi ukuran butir

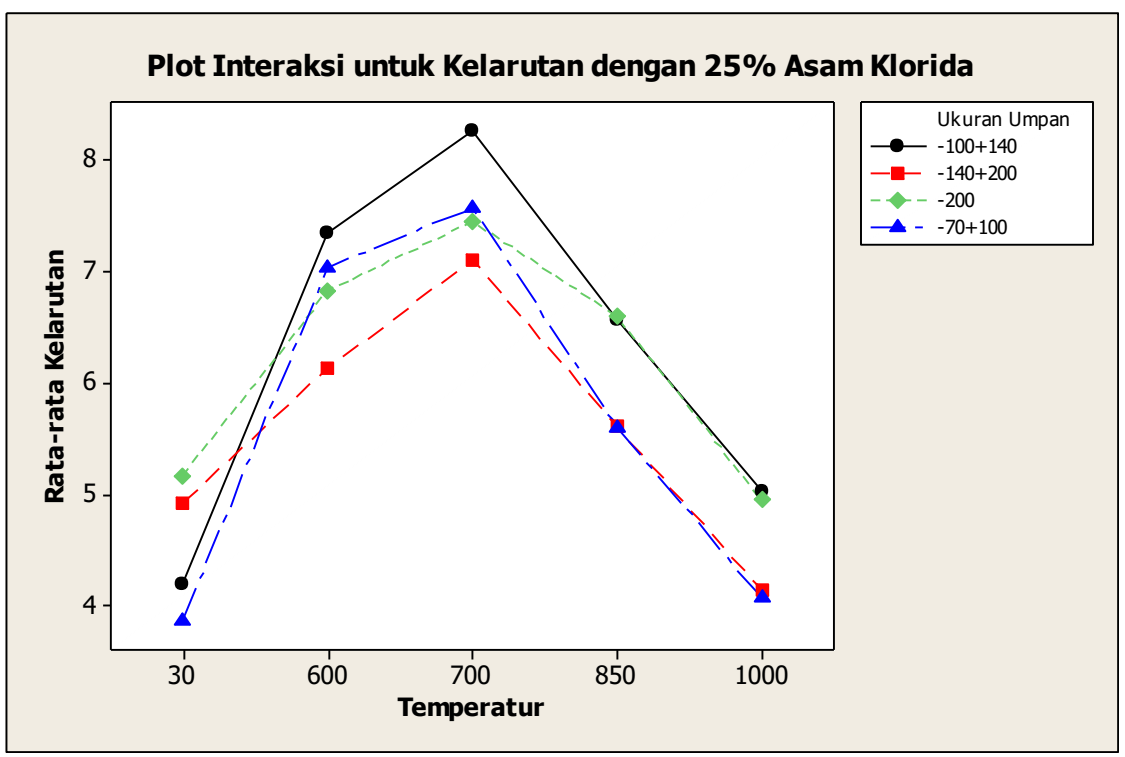

Gambar 8. Grafik kelarutan kalium dalam $25 \%$ asam klorida, variasi temperatur

Kelarutan dalam asam sitrat $2 \%$ tanpa pemanasan memberikan hasil relatif rendah antara 0,24-0,44 \%. Semakin halus butiran cenderung meningkatkan kelarutan. Kelarutan meningkat tajam terjadi pada suhu $600{ }^{\circ} \mathrm{C}$ antara 1,87-2,37\%. Saat suhu dinaikkan 700 ${ }^{\circ} \mathrm{C}$, kelarutan relatif tetap antara 2,00-2,36 \%, sedangkan pada peningkatan suhu $850{ }^{\circ} \mathrm{C}$ mulai terjadi penurunan kelarutan menjadi 1,25-1,87 \%. Ketika suhu dinaikan lebih tinggi lagi menjadi $1000{ }^{\circ} \mathrm{C}$, justru kelarutan semakin menurun menjadi 0,34-0,42\%.

Terjadi perbedaan hasil kelarutan yang cukup berarti bila menggunakan $25 \%$ asam klorida.
Bila kehalusan butiran berubah dari 70 sampai 200 mesh maka terjadi kelarutan antara 3,87$5,17 \%$. Semakin halus butiran semakin meningkat kelarutan. Pada suhu $600{ }^{\circ} \mathrm{C}$ kelarutan meningkat antara 7,03-7,33 \%, saat suhu dinaikkan $700{ }^{\circ} \mathrm{C}$, kelarutan sedikit meningkat antara 7,57-8,25 \%, pada peningkatan suhu $850^{\circ} \mathrm{C}$ mulai terjadi penurunan kelarutan menjadi 5,60-6,59 \%, ketika suhu dinaikan lebih tinggi lagi menjadi $1000{ }^{\circ} \mathrm{C}$ justru kelarutan menurun menjadi 4,07-5,03 \%. Kelarutan hanya dengan pengecilan ukuran butir, jika dibandingkan kelarutan setelah pemanasan meningkat mencapai 10 kali. Kelarutan tertinggi dengan 
asam klorida terjadi pada suhu $700{ }^{\circ} \mathrm{C}$, kehalusan butir $-100+140$ mesh yaitu 8,25\%. Kelarutan dengan asam klorida mampu meningkatkan kelarutan kalium pada batuan leusitik sebesar 3 kali dari percontoh tanpa pemanasan terhadap percontoh setelah pemanasan.

Dari hasil analisis percontoh yang diambil dari Medani menunjukkan kadar $\mathrm{K}_{2} \mathrm{O}$ tidak berbeda jauh dari refrensi yang dilakukan sebelumnya, demikian juga kadar $\mathrm{SiO}_{2}$ nya seperti ditampilkan pada Tabel 6 .

Jika dibandingkan kelarutan pada proses fusi alkali, proses melalui pemanasan relatif masih rendah, pada suhu $600{ }^{\circ} \mathrm{C}$, fusi alkali mencapai 8,37 \% sedangkan hanya melakukan pemanasan saja, kelarutan hanya 2,04 \%, tetapi fusi alkali perlu penambahan $\mathrm{NaOH}$ yang prosesnya relatif lebih sulit dan lebih mahal. Yang menarik adalah dengan peningkatan suhu di atas $800{ }^{\circ} \mathrm{C}$, kelarutan pada ke dua uji coba tersebut terjadi penurunan kelarutan kalium seperti ditampilkan pada Tabel 7.

\section{KESIMPULAN DAN SARAN}

\section{Kesimpulan}

Di daerah Jepara Pati terdapat banyak batuan basal yang mengandung mineral plagioklas, leusit, piroksen, biotit, sanidin, augit, dan opaq. Potensi batuan tersebut mencapai 532,550 juta ton, sedangkan di Dukuh Medani memiliki potensi 190,440 juta ton.

Karakteriktik dan komposisi mineral terdiri dari fenokris leusit (35\%), berukuran antara 0,4-19 mm, bentuk octagonal. Sanidin (4,8 \%) berukuran antara 0,5-4,7 $\mathrm{mm}$ bentuk subhedral, prismatik panjang, yang tertanam pada massa dasar microlit $(32,6 \%)$. Mineral sekunder yang hadir berupa mineral lempung $(13,6 \%)$ dan kalsit $(11,2 \%)$ sebagai ubahan dari mineral primer plagioklas. Karakteristik susunan geokimia mempunyai kadar $\mathrm{K}_{2} \mathrm{O}$ antara 6,91-9,32\%, $\mathrm{Al}_{2} \mathrm{O}_{3}$ antara 19,37-24,71 $\%$ dan $\mathrm{SiO}_{2}$ antara 47,35-48,73\%.

Tabel 6. Perbandingan hasil analisis senyawa kimia hasil penelitian terhadap referensi penelitian sebelumnya

\begin{tabular}{|c|c|c|}
\hline $\begin{array}{l}\text { No. } \\
\text { percontoh }\end{array}$ & $\begin{array}{l}\text { Hasil penelitian (AAS), } \\
\text { daerah Medani. }\end{array}$ & $\begin{array}{l}\text { Refrensi (Muksin dan Karangan, 2016) } \\
\text { (AAS) }\end{array}$ \\
\hline 1 & $\begin{array}{l}-\mathrm{K}_{2} \mathrm{O} 6,91 \% \\
-\mathrm{Al}_{2} \mathrm{O}_{3} 19,48 \% \\
-\mathrm{SiO}_{2} 47,35 \% \\
-\mathrm{CaO} 8,33 \%\end{array}$ & \\
\hline 2 & $\begin{array}{l}-\mathrm{K}_{2} \mathrm{O} 9,22 \% \\
-\mathrm{Al}_{2} \mathrm{O}_{3} 23,27 \% \\
-\mathrm{SiO}_{2} 47,85 \% \\
-\mathrm{CaO} 4,55 \%\end{array}$ & $\begin{array}{c}-\mathrm{K}_{2} \mathrm{O} \text { antara } 6,61 \text { s.d.7,87 \% } \\
-\mathrm{SiO}_{2} \text { antara } 46,88 \text { s.d. } 49,03 \%\end{array}$ \\
\hline 3 & $\begin{array}{l}-\mathrm{K}_{2} \mathrm{O} 7,88 \% \\
-\mathrm{Al}_{2} \mathrm{O}_{3} 20,24 \% \\
-\mathrm{SiO}_{2} 47,93 \% \\
-\mathrm{CaO} 7,00 \%\end{array}$ & \\
\hline
\end{tabular}

Tabel. 7. Perbandingan kelarutan kalium batuan leusitik diproses fusi alkali $(\mathrm{NaOH})$, versus uji pemanasan saja pada ukuran butir 140 mesh

\begin{tabular}{cccc}
\hline \multirow{2}{*}{ No. } & Temperatur $\left({ }^{\circ} \mathrm{C}\right)$ & \multicolumn{2}{c}{ Kelarutan kalium dalam asam sitrat 2\% } \\
\cline { 3 - 4 } & 500 & Uji fusi alkali & Uji pemanasan \\
\hline 1 & 600 & $7,36 \%$ & - \\
2 & 700 & $8,37 \%$ & $2,04 \%$ \\
3 & 800 & $9,07 \%$ & $2,05 \%$ \\
4 & 900 & $9,13 \%$ & $1,84 \%$ \\
5 & $8,36 \%$ & $0,43 \%$ \\
\hline
\end{tabular}

(Wahyudi $d k k ., 2012)$ 
Hasil penelitian dengan pengecilan ukuran butir dan peningkatan temperatur, menunjukan bahwa semakin halus ukuran (dari 70-200 mesh) terjadi peningkatan kelarutan kalium dari 0,22-0,49\%, sedangkan pada peningkatan temperatur $600{ }^{\circ} \mathrm{C}$ kelarutan mencapai 2,57 \% (menggunakan $2 \%$ asam sitrat). Pelarutan menggunakan $25 \% \mathrm{HCl}$, kelarutannya mencapai 3,4-5,3 \%, bahkan masih meningkat pada suhu $700{ }^{\circ} \mathrm{C}$ yaitu mencapai $8,1 \%$.

\section{Saran}

Dalam penelitian ini sudah terbukti adanya peningkatan kelarutan kalium yang berasal dari mineral leusit, karena itu perlu diuji pemanfaatannya pada tanaman semusim seperti jagung, kedelai, kacang tanah.

\section{UCAPAN TERIMAKASIH}

Penulis mengucapkan terimakasih kepada Kepala Badan Penelitian dan Pengembangan Energi dan Sumber Daya Mineral, Kepala Pusat Penelitian dan Pengembangan Teknologi Mineral dan Batubara yang telah memfasilitasi penelitian ini.

Ketua Program Studi Sumberdaya Mineral, Dekan Fakultas Teknik Geologi Universitas Padjadjaran Bandung yang telah memberikan arahan, serta semua pihak yang telah membantu sehingga terlaksananya penulisan ini.

\section{DAFTAR PUSTAKA}

Agung, B., Purnomo, H., Saleh, R., Suganal, Handayani, S., Pranoto, E. dan Sulistyani, L. (2015) Pupuk bio organo mineral untuk tanaman teh di Gambung. Bandung: Puslitbang tekMIRA.

Ciceri, D., Manning, D. A. C. dan Allanore, A. (2015) "Historical and technical developments of potassium resources," Science of The Total Environment, 502, hal. 590-601.

doi: 10.1016/j.scitotenv.2014.09.013.

Erpian, R., Agung, B. dan Budiman, S. (2011) Pembuatan garam epsom (MgSO4.7H2O) dari mineral talk (magnesium silikat). Universitas Jenderal Achmad Yani.
Han, Y. X., Liu, J. dan Yin, W. Z. (2008) "Research on the mechanism of the dissociation of potassium shale during roasting," Advanced Materials Research, 58, hal. 155-162. doi: 10.4028/www.scientific.net/AMR.58.155.

Jasinski, S. M. (2016) Potash, www.usgs.gov. Tersedia pada:

https://minerals.usgs.gov/minerals/pubs/com modity/potash/mcs-2016-potas.pdf (Diakses: 10 Januari 2019).

Muksin, I. dan Karangan, C. (2016) "Prospeksi batuan pembawa kalium Kabupaten Pati, Provinsi Jawa Tengah," in Prosiding Hasil Kegiatan Tahun 2016 Pusat Sumber Daya Mineral, Batubara dan Panas Bumi. Bandung: Pusat Sumber Daya Mineral, Batubara dan Panas Bumi, hal. 245-252.

Saleh, R., Purnomo, H., Wahyudi, T., Jafril, Anugrah, R. I., Pranoto, E., Rachmiati, Y. dan Trikamulyana, T. (2014) Kajian pasar pupuk majemuk berbasis mineral pada tanaman teh. Bandung: Puslitbang tekMIRA.

Sayekti, B. (2015) Batuan vulkanik kaya kalium untuk agromineral daerah Ngabinan dan Gebangan Situbondo Jawa Timur. Universitas Padjadjaran.

Soenara, T., Ardha, N., Purnomo, H., Rasyad, S. S., Hermana, Y., Rustandi, D., Sudirman, A. dan Priatna, D. (2011) Peningkatan kinerja proses dan peralatan pengolahan mineral skala pilot di Cipatat. Bandung: Puslitbang tekMIRA.

Streckeisen, A. (1980) "Classification and nomenclature of volcanic rocks, lamprophyres, carbonatites and melilitic rocks - IUGS subcommission on the systematics of igneous rocks," Geologische Rundschau, 69(1), hal. 194-207. doi: 10.1007/BF01869032.

Sudradjat, A., Permana, D., Haryadi, H., Arifin, M., Mulyono, H. P., Saleh, R., Suhendar, Supriatna, S., Kunrat, T. S., Suseno, T. dan Mandalawanto, Y. (1997) Bahan galian industri. Diedit oleh S. Supriatna dan M. Arifin. Bandung: Puslitbang tekMIRA.

Suganal, Saleh, N., Yuhelda, Amalia, D. dan Supriyanto, B. A. (2016) Pengembangan dan aplikasi hasil litbang pengolahan dan pemurnian mineral mendukung peningkatan nilai tambah mineral. Bandung: Puslitbang tekMIRA.

Vogel, A. I. dan Svehla, G. (1979) Textbook of macro and semimicro qualitative inorganic 
analysis. 5t Ed. Longman Scientific \& Technical.

Wahyudi, T., Handayani, S., Ardha, N., Suratman, Cahyono, S. S. dan Amirudin, D. (2008) Pengembangan bioteknologi untuk pengolahan mineral: Studi kasus ekstraksi fosfat dari endapan fosfat alam dengan metode bio. Bandung: Puslitbang tekMIRA.

Wahyudi, T., Purnomo, H., Wahyudi, A., Rochani, S., Soenara, T., Simanjuntak, W., Damayanti, R., Sulistyani, L., Hermana, Y., Sofyan, Y., Sudirman, A., Rustandi, D., Rohayati, Y., Alamanda, N., Fitria, F., Ernawati, Juarsa dan Pendi, S. (2012)
Pemrosesan mineral untuk bahan pupuk skala pilot. Bandung: Puslitbang tekMIRA.

Wang, C., Yue, H., Li, C., Liang, B., Zhu, J. dan Xie, H. (2014) "Mineralization of CO2 using natural K-Feldspar and industrial solid waste to produce soluble potassium," Industrial \& Engineering Chemistry Research, 53(19), hal. 7971-7978. doi: 10.1021/ie5003284.

Wardama, I. W. dan Titisari, A. D. (2004) Agromineralogi: Mineralogi untuk ilmu pertanian. Yogyakarta: Universitas Gadjah Mada. Tersedia pada:

http://warmada.staff.ugm.ac.id/Buku/agromin eral.pdf. 
